\title{
STORAGE OF PLANTING STOCK IN THE FIELD ${ }^{1}$ By R. E. MULLIN ${ }^{2}$
}

\section{INTRODUCTION}

When packaged trees arrive at a planting site some time before planting can begin, the planting officer is faced with a choice of four procedures to preserve the viability.

\section{Refrigerated Storage}

Refrigerated space is available in some locations, and the requirements for storage are known (Burns, 1961; Deffenbacher and Wright, 1954; Duffield and Eide, 1959; Fowells and Schubert, 1953). Refrigeration of stock stored in sealed polyethylene bags may be dangerous, as mold is apt to develop if the cooling is not rapid (Mahlstede and Fletcher, 1960). The trees must be hardened off and dormant before being placed in storage (Kahler and Gilmore, 1961).

\section{Field Storage in Packages}

The packages (bales, crates, polyethylene or paper bags), may be left intact and placed in a shaded and sheltered location. Watering at intervals must be considered. In a test of short term storage (10 or 20 days) it was found that a complete wrap in polyethylene sheeting gave better results than other methods of packaging examined, which included a resin dip, sisalkraft paper, and straw and moss (around tops and roots respectively) (Faulkner and Aldhous, 1957 a). This was confirmed by later tests (up to 30 days) and polyethylene bags came into general use for nursery shipment in Great Britain (Faulkner and Aldhous, 1957 b; 1959). Exposure to sunlight was a problem encountered in the use of polyethylene, in addition to fungal activity and heating (Aldhous, 1959). Trees in the bags tended to remain dormant longer than trees left in the ground, or trees transplanted immediately after lifting (Aldhous, 1959).

\section{Heeling-in}

The packages may be opened and the trees heeled-in (placed in shallow trenches) in a suitable location, either with the trees in single rows of bundles or with the bundles broken. Watering at intervals must be considered. This method is probably the most common. It has been recommended by many authorities, some of whom have prescribed rather elaborate conditions (Anonymous, 1946; Daskevitsh, 1960; Faulkner and Aldhous, 1956; Holmes and Faulkner, 1955; Rudolf, 1950; Wakeley, 1935).

On the other hand, the benefits of heeling-in have been questioned. Wakeley (1954) found very little difference between the effects of heeling-in and leaving in bales, when the trees were lifted during the normal planting season. Ursic (1956) observed lower survival of trees heeled-in than of trees left in crates, but better height growth of the heeled-in trees (only when the bundles were opened and spread). Meschke (1957) observed that heelingin may cause " $\mathrm{L}$ " shaped roots to develop, promote root rot in excessively

\footnotetext{
${ }^{1}$ Contribution No. 62-3, Ontario Department of Lands and Forests.

Dr. Mullin is employed by the Research Branch, Ont. Dept. of Lands and Forests, Maple, Ontario.
} 
wet locations, and physical damage to fine rootlets. Cossitt (1961) found that stock left in bales in a cool place and watered at frequent intervals gave survival as good or better than stock heeled-in in the best possible manner, for periods up to 5 weeks. Horvath (1958) concluded that heeling-in had an adverse effect on seedlings, especially on the root systems, as shown by poorer survival and decrease of weight.

\section{Mounding or Circle-piling}

In this method of storage the packages are opened and the trees piled in circular mounds, with the roots inwards, placing moss in layers between the roots. A shaded and sheltered location for the piles is desired. A cut sod may be placed on top to shelter the roots from sun and wind and to provide rigidity. Watering at intervals must be considered.

The problem of comparing methods of storage involves cognizance of differences caused by the length of the storage period. Ursic (1956) found that storage up to five weeks had no effect on survival. Harvey (1961) found that transit and holding periods of two weeks or less had little effect on field survival of either refrigerated or freshly lifted stock. On the other hand another study showed that storage up to 16 days in paper packages resulted in poorer growth (Yli-Vakkuri, 1957). Fowells and Schubert (1953) found that the longer the storage period, the shorter the terminal growth in the year of planting. In another instance holding trees for two days caused an increase in mortality (Afanasiev et. al. 1959).

It has already been observed, from similar conflicting information, that it is difficult to compare the results of the numerous storage studies, or to draw generalized conclusions (Stone and Schubert, 1959). In addition to species differences there are many variations in the stock and in the storage conditions. Loss of height growth may occur if the stock is lifted during the flush of growth (Crossley, 1956), or if the stock is held during the best part of the growing season (Stoeckeler and Jones, 1957). If new growth develops during storage, it will be etiolated and succulent, usually resulting in later loss of shoots (Toy and Mahlstede, 1960).

An earlier study in Ontario, which compared storage in bales with that in crates showed only minor differences, (Leech, 1959; Mullin 1954). This study, however, lacked a comparison with heeling-in, or other methods, and the further studies reported herein were undertaken to obtain more information on the problems of field storage at the planting site.

\section{Experiment A. Established 1956}

\section{METHODS AND MATERIALS}

This experiment tested four methods of field storage, as follows:

1. Bales: Standard size, approximately 16 in. diameter, burlap bales (Mullin, 1956).

2. Crates: Standard size, approximately 18 in. $x 20$ in. $x 36$ in. wooden crates.

3. Heeled-in: Trees for this treatment were shipped in bales and carefully heeled-in in a shaded, moist area near the planting site.

4. Circle-piling: The trees for this treatment were shipped in crates and piled at the storage area in circular mounds using the moss from the crates around the roots. A cut sod was placed on top. 
Regular 2-2 white spruce (Picea glauca (Moench) Voss) seedlings were packed at St. Williams Nursery, about 100 miles southwest of Toronto near Lake Erie, on April 16, 1956. The packing was done by a single crew, according to a randomized list which assigned treatments and planting dates to each unit as completed. The trees were transported by truck to the planting area at Larose Forest, about 20 miles southeast of Ottawa, the following day. They were immediately stored in the selected area, a young pine plantation.

The experiment consisted of 12 units (e.g. 12 bales) for each of the four methods of storage. Two units of each method were used at each of the six planting dates which started a week later, on April 24, and continued at weekly intervals. From each unit (i.e. a bale) four random samples of 49 trees were selected and planted, according to a randomized design. An internal Latin square design, involving the four planting methods and four planting crews, was used to control possible differences due to planting crews. The total planting required 192 plots (4 methods $\times 6$ planting dates $\times 8$ replications $=192$ ), containing 9,408 trees. At each planting date the remaining storage units were watered, using one pail (about $1 \frac{1}{2}$ Imperial gallons) per unit. They were also exposed to rain.

At the end of the first growing season a count of living trees was made. At the end of the fifth growing season a height measurement of all living trees was obtained.

\section{Experiment B. Established 1960}

This experiment tested eight methods of field storage, as follows:

1. Bales: Standard size, not watered.

2. Bales, watered; Standard size but watered at weekly intervals.

3. Circle-piling: Same procedure as in previous experiment except that trees were shipped in bales, rather than crates. This provided a smaller pile (about 500 2-2 white spruce compared to 2,000), not watered.

4. Circle-piling, watered: Same procedure as above (3) but watered at weekly intervals.

5. Heeled-in: Same procedure as in previous experiment, not watered.

6. Heeled-in, watered; As in method 5 but watered at weekly intervals.

7. Polyethylene Bags: A handful of wet moss was placed in the bottom of a bag, 30 in. $x 40$ in. of clear 3 mil. polyethylene. Ten bundles (25 trees each) of trees were placed erect in the bag which was then tied with twine.

8. Paper Bags: Same procedure as in 7, using a multi-walled paper bag, 24 in. $x 30$ in., with a polyethylene lining. These bags were stapled across the folded top edges.

The packing was done on May 4, 1960 at the Kemptville nursery, about 30 miles south of Ottawa, using regular 2-2 white spruce. A randomized list was again used to direct the packing crew in the order in which to pack each unit and to assign completed units to a particular planting date. The packages were taken to the storage area at Limerick Forest, about 30 miles southwest of Ottawa, on the same day and established in the required storage methods. There were 56 storage units, seven of each method, to provide for the seven planting dates at weekly intervals. 
The trees for the first planting, May 5, were left in packages, not watered, heeled-in or circle-piled. The remaining trees were stored in a shady grove adjacent to the planting area. At each planting date five samples of 49 trees each were randomly selected from each of the eight storage units randomly selected for planting on that date. Four planting crews of two men each were used throughout the experiment. Each crew planted a plot of 49 trees by taking turns on the planting and carrying. No record was kept of the two treatments, in each replication, planted by each crew. These were assigned in a random order and changed with replications. This method was considered acceptable as differences due to planting crews were not significant in the previous experiment. The total planting required 280 plots, ( 8 methods $x 7$ planting dates $\times 5$ replications $=280$ ), containing 13,720 trees.

Maximum and minimum thermometers were inserted in the units being held for the last planting and these were read at the weekly planting date. A recording thermocouple was placed at ground level in the storage area for continuous temperature records. A detailed description was obtained also of each storage unit as it was opened or used for planting.

At the end of the first growing season a count was made of living trees and the length of the terminal leaders was measured.

\section{Experiment A}

RESULTS

A summary of the data obtained from Experiment $A$, which compared four storage methods, is presented in Table 1 .

TABLE 1

EXPERIMENT A, ESTABLISHED 1956

a. FIRST-YEAR, MORTALITY
(Out of 392 trees; 8 replications of 49 trees each)

\begin{tabular}{|c|c|c|c|c|c|c|c|}
\hline & \multicolumn{7}{|c|}{ Date of Planting } \\
\hline & $\begin{array}{c}\text { April } \\
4\end{array}$ & $\begin{array}{c}\text { May } \\
1\end{array}$ & $\begin{array}{l}\text { May } \\
8\end{array}$ & $\begin{array}{c}\text { May } \\
15\end{array}$ & $\begin{array}{c}\text { May } \\
22\end{array}$ & $\begin{array}{c}\text { May } \\
29\end{array}$ & Totals \\
\hline Bales, watered & 67 & 137 & 29 & 16 & 46 & 42 & 337 \\
\hline Heeled-in, watered & 76 & 110 & 41 & 28 & 7 & 13 & 275 \\
\hline Crates, watered & 68 & 104 & 19 & 35 & 7 & 16 & 249 \\
\hline Circle-piled, watered & 55 & 68 & 17 & 63 & 4 & 9 & 216 \\
\hline Totals.. & 266 & 419 & 106 & 142 & 64 & 80 & 1077 \\
\hline $\begin{array}{l}\text { b. FIFTH-YEAR, MORTALITY } \\
\text { Bales, watered }\end{array}$ & 90 & 176 & 92 & 65 & 99 & 73 & 595 \\
\hline Heeled-in, watered & 94 & 141 & 99 & 62 & 32 & 55 & 483 \\
\hline Crates, watered & 88 & 159 & 85 & 77 & 60 & 45 & 514 \\
\hline Circle-piled, watered & 97 & 85 & 77 & 109 & 68 & 23 & 459 \\
\hline Totals & 369 & 561 & 353 & 313 & 259 & 196 & 2051 \\
\hline c. FIFTH-YEAR, HEIGHT & for & ing & & & & & \\
\hline Bales, watered & 1.82 & 1.88 & 1.68 & 1.64 & 1.94 & 1.91 & 1.80 \\
\hline Heeled-in, watered & 1.89 & 1.95 & 1.74 & 1.67 & 1.96 & 1.67 & 1.81 \\
\hline Crates, watered & 2.04 & 1.86 & 1.83 & 1.75 & 1.84 & 1.84 & 1.86 \\
\hline Circle-piled, watered & 1.67 & 1.78 & 1.95 & 1.80 & 1.96 & 1.92 & 1.85 \\
\hline Average & 1.86 & 1.86 & 1.80 & 1.71 & 1.93 & 1.84 & 1.83 \\
\hline
\end{tabular}


Although it would appear that the mortality decreased with the lengthening of the storage period this was not statistically supported.

The differences in total height, due to the date of planting, were significant at the 5.0 per cent level. The average height of the trees planted on May 15 was significantly lower, and that of those planted on May 22 significantly higher than the average heights of the remainder.

No significant differences were found in either survival or growth due to the method of storage.

\section{Experiment B}

A summary of the data obtained from Experiment B, which compared eight storage methods is presented in Table 2.

Examination of the mortality data, representing all dates of planting, by analysis of variance did not show any significant differences corresponding to the eight methods of field storage tested. The high mortality in this experiment was due to the exceptionally severe drought conditions in August and September of 1960, and the shallowness of the soil. The increase in mortality with time, was significant at the 0.1 per cent level.

Because of excessive mortality in the last three planting dates, and because the trees used for the first planting were fresh rather than stored,

TABLE 2

EXPERIMENT B, ESTABLISHED 1960

a. FIRST-YEAR, MORTALITY

\begin{tabular}{|c|c|c|c|c|c|c|c|c|}
\hline & \multicolumn{8}{|c|}{ Date of Planting } \\
\hline & $\begin{array}{c}\mathrm{May} \\
5\end{array}$ & $\begin{array}{c}\text { May } \\
12\end{array}$ & $\begin{array}{c}\text { May } \\
19\end{array}$ & $\begin{array}{c}\text { May } \\
26\end{array}$ & $\begin{array}{c}\text { June } \\
2 \\
\end{array}$ & $\underset{9}{J u n e}$ & $\begin{array}{c}\text { June } \\
16\end{array}$ & Totals \\
\hline Bales & 131 & 161 & 190 & 224 & 202 & 234 & 235 & 1377 \\
\hline Bales, watered & 196 & 150 & 154 & 220 & 240 & 243 & 245 & 1448 \\
\hline Heeled-in & 141 & 135 & 186 & 216 & 217 & 240 & 242 & 1377 \\
\hline Heeled-in, watered & 125 & 144 & 131 & 229 & 213 & 241 & 241 & 1324 \\
\hline Circle-piled & 169 & 198 & 192 & 205 & 173 & 221 & 224 & 1382 \\
\hline Circle, watered & 162 & 160 & 183 & 193 & 217 & 245 & 243 & 1403 \\
\hline Polyethylene bags & 146 & 131 & 159 & 227 & 245 & 211 & 242 & 1361 \\
\hline Paper bags & 147 & 133 & 189 & 201 & 245 & 244 & 245 & 1404 \\
\hline Totals & 1217 & 212 & 1384 & 1715 & 1752 & 1879 & 1917 & 11,076 \\
\hline
\end{tabular}

b. FIRST-YEAR, LEADER LENGTHS

\begin{tabular}{|c|c|c|c|c|c|c|}
\hline .232 & .203 & .218 & .143 & .169 & .164 & .155 \\
\hline Bales, watered. & .211 & .229 & .203 & & & - \\
\hline Heeled-in & .230 & .236 & .217 & .192 & & 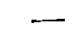 \\
\hline Heeled-in, watered _--.. .221 & .211 & .235 & .219 & .166 & - & - \\
\hline Circle-piled .237 & .169 & .238 & .154 & .126 & .158 & .190 \\
\hline Circle-watered & .227 & .207 & .202 & .158 & 一 & - \\
\hline olyethylene bags & .222 & .171 & .191 & - & .045 & - \\
\hline Paper bags 229 & .238 & .187 & .088 & & & \\
\hline Average & .218 & .215 & .171 & .155 & .123 & .178 \\
\hline
\end{tabular}

(Blanks indicate less than 10 surviving trees, hence average leader length unreliable or not available). 
an analysis was conducted on the mortality data representing holding periods of 1, 2 and 3 weeks (May 12, 19, and 26). The interaction, treatment $\mathbf{x}$ date of planting, reached significance at about the 2.5 per cent level. This indicated that the treatments which gave the greatest consistent survival at the end of the first week, did not continue to do so at the end of the second and third weeks. This will be discussed further.

The data obtained from the leader-length measurements in Experiment B are also summarized in Table 2. Because of the absence of data for growth in the last three planting dates, and because the first planting (May 5) was actually unstored, an analysis for the three week period (May 12, 19, and 26) was conducted as done previously for mortality. The interaction for treatment $\mathrm{x}$ date of planting was again significant, at the 0.1 per cent level. This indicated that the method of storage had an influence on the extent of terminal growth which changed in relative position and magnitude with the length of storage.

\section{Discussion}

\section{Length of Storage Period}

The normal supposition is that mortality will be expected to increase with the length of unrefrigerated storage. This may be due to heating, development of molds or advance of less favourable planting weather. This general trend has been observed in many experiments (Mullin, 1954; 1956; 1958) and occurs, with very high statistical signficance in Experiment $B$.

However, in Experiment A, almost a reverse pattern seems to have occurred. The greatest mortality was in trees which had been stored for one or two weeks although the differences between planting dates were not statistically significant. Other experiments have also recorded little or no increase in mortality with length of the storage period (Harvey, 1961; Ursic, 1956; Wakeley, 1954). The explanation for these conflicting results may be that the effects of length of storage period are confounded with differences in physiological condition of the stock at time of packing (degree of dormancy) and with differences in weather and soil conditions at the successive planting dates.

Study of the weather conditions for 1956 suggests reasons for the higher mortality of the trees planted on the early planting dates. Rainfall in April was about 45 per cent above normal. Exceptionally heavy rainfall of about 1.50 inches and 0.70 inches occurred between the first and second plantings. Poor drainage was possibly sufficient to result in root rot. There were also heavy frosts and cool days. This weather presented excellent conditions for storage but not for planting.

The effect of the length of the storage on growth must also be considered. In Experiment $\mathrm{B}$ it was found that leader-length generally decreased with length of storage, although there were significant differences in magnitude between storage methods. This trend has been observed in other experiments (Yli-Vakkuri, 1957; Fowells and Schubert, 1953). The explanation usually given for the decrease is that the trees in storage have passed part of the growing season without the opportunity to develop normally.

In the case of Experiment A, however, the foregoing pattern was not recognized. Rather, it was found that the growth of the trees planted on 
May 15 (stored 4 weeks) was poorest, and that of the trees planted a week later (May 22) was best. The spring weather in 1956 was cold and with heavy frost. Probably all the early plantings were severely damaged by frost, up to and including that of May 15. The stored trees were perhaps breaking dormancy by May 15, and received heaviest damage due to their physiological condition. By May 22 the trees in storage had progressed further from dormancy and were not as severely damaged by frost, which occurred after planting but which was, however, less severe. By the last planting, May 29, the loss of growth was subjected to the usual decline due to loss of part of the growing season.

\section{Comparisons of Storage Method}

In the data from Experiment $A$, no significant terms were found for the variation representing treatments (storage methods), or for interactions containing this term. In Experiment B, however, analysis of the data representing 1,2 and 3 weeks of storage, showed significance for the treatments $x$ dates interaction in both mortality (at 1.0\%) and growth (at $0.1 \%$ ). Hence our inferences must be drawn mostly from Experiment B.

Mortality at the end of the first season (Table 2) was lowest for the trees which had been stored for one week (May 12 planting) in polyethylene bags, paper bags, and unwatered heeling-in beds $(131,133$ and 135 respectively). Those stored for two weeks (May 19 planting) showed the least mortality from the watered heeling-in beds, watered bales and polyethylene bags (131, 154 and 159 respectively). For a storage period of three weeks (May 26 planting) mortality was least for watered circle-piling, paper bags, and unwatered circle-piling (193, 201 and 205 respectively).

The differences in leader-length do not conform in respect to the above distinctions between storage methods. For example, by the end of the first week, although the growth of trees previously stored in paper bags and heeled-in was better, that of trees stored in polyethylene bags was not in the highest group. By the end of the second week growth of trees kept in the polyethylene and paper bags was much retarded. By the end of the third week the best growth was achieved by both heeling-in methods although not the best survival.

The containers of polyethylene and paper, which gave good results for storage up to one week, reached the highest temperatures, and caused the greatest degree of bud development in that time. By the end of the second week the paper bag storage resulted in the greater extent of development, and higher temperature. This was followed by lower survival. Storage in the paper bag package resulted in better survival of trees stored for three weeks than the polyethylene, perhaps because there was less mold.

The question of watering the storage units was not fully resolved. For storage up to three weeks, weekly watering of bales gave better survival and growth. Watering of heeling-in beds did not give consistent benefit and in some instances appeared harmful. This may have been due in part to the effects of moisture on the ease of lifting (Leech, 1961). Watering of the circle-piles gave better survival up to three weeks but not consistently better growth. 
It is obvious that no one storage method is superior for all storage periods in terms of both survival and growth. It is necessary in assessing the comparative qualities of the methods, to stipulate some maximum storage period.

\section{CONCLUSIONS}

The results of these two studies indicate that successful field storage depends largely upon the weather conditions, being substantially increased by cold weather. The occurrence of frost at night, of as low as $24^{\circ} \mathrm{F}$. does not seem to result in damage. Storage in the spring, after the growing season has begun, may increase mortality and decrease growth. Although this is the general expectancy, the weather and site conditions of a particular planting date or season may exert influences far in excess of those of storage.

Significant differences were found between the storage methods examined, in terms of effects on survival and growth. However, no one method was better, consistently over the entire storage period. Some were better for short periods, some for long periods.

For normal storage of less than two weeks the clear polyethylene bags appear to be superior. For periods of storage up to three weeks the trees should be placed in circle-piles and watered.

\section{ACKNOWLEDGEMENTS}

The author wishes to express his sincere appreciation to Professor Emeritus T. W. Dwight for advice and assistance in compilation and analysis of the data; and to Mr. D. H. Burton, Mr. D. P. Fowler and Dr. C. C. Heimburger, for reviewing of the manuscript.

Mr. J. L. Mullen ably supervised in the planting, observing and counting of the 1956 experiment at Larose Forest, and Mr. A. J. Campbell supervised the arranging and planting of the 1960 experiment at Limerick Forest.

\section{REFERENCES}

AFANASIEV, Michel; ENGSTROM, Albert; and JOHNSON, Ernest W., 1959. Effects of Planting Dates and storage on survival of Eastern Red Cedar in central and western Oklahoma. Oklahoma State University. Bull. B-527.

ALDHOUS, J. R., 1959. Polythene bags for movements of forest nursery stock. Emp. For. Rev. $38(1): 65-76$

ANONYMOUS, 1946. Forestry Practice. Forestry Commission. Bull. No. 14. London.

BURNS, R. M., 1961. Cold-stored hardwoods survive delayed planting. Southern Forest Experiment Station. U.S.F.S. Southern Forestry Notes No. 131.

COSSITT, F. M., 1961. Seedling storage in bales. Tree Planters' Notes. U.S.F.S. No. 45. March 1961: 11-12.

CROSSLEY, D. I., 1956. The possibility of continuous planting of white spruce throughout the frost-free period. Canada Forestry Branch. For. Res. Div. Tech. Note No. 32.

DASKEVITSH, M. D., 1960. Don't leave roots of seedlings exposed. Lesnoe Khoziaistvo. No. 4. Vol. 12. Abstract only seen: translated by Fedor Kudrjavcev. Oregon Forest Research Centre. Corvallis, Oregon.

DEFFENBACHER, Forrest W. and WRIGHT, Ernest, 1954. Refrigerated storage of conifer seedlings in the Pacific northwest. J. of For. 52: 936-938.

DUFFIELD, John W. and EIDE, Rex P., 1959. Polyethylene bags for packaging of conifer planting stock in the Pacific northwest. J. of For. 57: 578-579.

FAULKNER, R, and ALDHOUS, J. R., 1956. Nursery investigations. Forestry Commission. Report on Forest Research for the year ended March 1955: 16-32. London.

1957a. Nursery investigations. Forestry Commission. Report on Forest Research for the year ended March 1956: 19-35. London. 


\footnotetext{
1957 b. Nursery investigations. Forestry Commission. Report on Forest Research for the year ended March 1957: 19-36. London.

1959. Nursery investigations. Forestry Commission. Report on Forest Research for the year ended March 1958: 20-37. London.
}

FOWELLS, H. A. and SCHUBERT, G. H., 1953. Planting stock storage in the California pine region. U.S.F.S. California Forest and Range Experiment Station. Tech. Paper No. 3.

HARVEY, George M., 1961. Effects of refrigeration and shipping on sugar pine field survival. Tree Planters' Notes. No. 45. March 1961: 17.

HOLMES, G. D. and FAULKNER, R., 1955, Experimental work in nurseries. Forestry Commission. Report on Forest Research for the year ending March 1954: 5-18. London.

HORVATH, I., 1958. Theoretical problems of raising P. sylvestris seedlings. 1. Heeling-in of one-year-olds. Abstract only seen; Forestry Abstracts 21(1) 1960. No. 446.

KAHLER, L. H. and GILMORE, A. R., 1961. Field survival of cold stored Loblolly pine seedlings. Tree Planters' Notes. No. 45. March 1961: 15-16.

LEECH, R. H., 1959. A second look at a nursery stock packaging experiment. For. Chron. 35 (1). March 1959: 36-49.

1961. Moisture relations of nursery stock. Ontario Department of Lands and Forests. Res. Rep. No. 45.

MAHLSTEDE, J. P. and FLETCHER, W. E., 1960. Storage of nursery stock. American Association of Nurserymen, Inc. and Iowa State University.

MESCHKE, K. G., 1957. Handling of seedlings in transit and planting. Per Weetman, G. F., 1958. Forest seeding and planting techniques and equipment. Pulp and Paper Research Institute of Canada. Montreal. Tech, Rep. No. 74.

MULLIN, R. E., 1954. Nursery stock packaging experiment. Ontario Department of Lands and Forests. Res. Rep. No. 27.

1956. Moisture retaining materials for nursery stock packaging. Ontario Department of Lands and Forests. Res. Rep. No. 34.

1958. An experiment with wrapping materials for bales of nursery stock. Ontario Department of Lands and Forests. Res. Rep. No. 37.

RUDOLF, Paul O., 1950. Forest plantations in the Lake States. U.S.D.A. Tech. Bull. No. 1010. STOECKELER, J. H, and JONES, G. W., 1957. Forest nursery practice in the Lake States. Forest Service. U.S.D.A. Agriculture Handbook No. 110.

STONE, Edward C. and SCHUBERT, Gilbert H., 1959. The physiological condition of ponderosa pine (Pinus ponderosa Laws.) planting stock as it affects survival after cold storage. J. of For. 57: 837-841.

TOY, S. J. and MAHLSTEDE, J. P., 1960. Prolonging dormancy of nursery stock by increasing the concentration of carbon dioxide in the storage atmosphere. Proc. Amer. Soc. for Hort. Sc. 75: 774-784.

URSIC, S. J., 1956. Bale storage effective for loblolly pine seedlings, J. of For. 54: 815-816.

WAKELEY, Philip C., 1935. Artificial reforestation in the southern pine region. U.S.D.A. Tech. Bull. No. 492. No. 18

YLI-VAKKURI, P., 1957. Investigations into the packing and transport of plants. Abstract only seen, Forestry Abstracts 19 (3) 1958. No. 2971 